\title{
KINERJA PERAWAT DALAM MEMBERIKAN ASUHAN KEPERAWATAN BERPENGARUH TERHADAP KEPUASAN PASIEN RAWAT INAP
}

\author{
Khamida*, Mastiah** \\ Fakultas Keperawatan dan Kebidanan \\ Universitas Nahdlatul Ulama Surabaya J1. Smea 57 Surabaya \\ E-mail:khamida@unusa.ac.id/ tiahtiahtiah@gmail.com
}

\begin{abstract}
Abstrack. The performance of nurses in providing nursing care is still considered unsatisfactory by the patient. The purpose of this study is to find out the relationship of the performance of nurses in providing nursing care with patient's satisfaction in Multazam ward of Surabaya Islamic Hospital. Design of this studied Analytical survey. The population were all patients in Multazam ward of Surabaya Islamic Hospital with amount 85 person. Number of sample were 39 respondents, taken by simple random sampling. The independent variable is performance of nurses in providing nursing care, dependent variable is patient's satisfaction. Instruments use questionnaires, data were processed by editing, coding, scoring, and tabulating, then analyzed by Chi-Square test with significant level $\alpha=\mathbf{0 . 0 5}$. Study result showed most of respondents $39(51.3 \%)$ the nurse had a poor performance, and most them $(56,4 \%)$ the patients are not satisfied. Results of Chi-Square test analysis showed p $(0.038)<\alpha(0.05)$, so $\mathrm{HO}$ is rejected means there is relationship of the performance of nurses in providing nursing care with patient's satisfaction in Multazam ward of Surabaya Islamic Hospital. The conclusions of this study is the performance of nurses in providing nursing care influence to the patient satisfaction. Nurses should responsive to the complaints and expectations of patients due.
\end{abstract}

Abstrak. Kinerja perawat dalam memberikan asuhan keperawatan masih dianggap tidak memuaskan oleh pasien. Penelitian ini bertujuan untuk mengetahui hubungan kinerja perawat dalam memberikan asuhan keperawatan dengan kepuasan pasien rawat inap di ruang Multazam Rumah Sakit Islam Surabaya. Desain penelitian survei analitik. Populasi seluruh pasien rawat inap di ruang Multazam Rumah Sakit Islam Surabaya sebesar 85 orang. Sampel sebesar 39 responden, diambil secara Simple Random Sampling. Variabel independen kinerja perawat dalam memberikan asuhan keperawatan, variabel dependen kepuasan pasien. Instrumen menggunakan kuesioner, diolah melalui editing, coding, scoring, dan tabulating, dianalisis menggunakan uji Chi-Square dengan tingkat signifikan $\alpha=0,05$. Hasil penelitian dari 39 responden sebagian besar $(51,3 \%)$ perawat memiliki kinerja kurang, dan sebagian besar $(56,4 \%)$ pasien menyatakan tidak puas. Hasil analisis uji Chi-Square menunjukkan $\rho$ $(0,038)<\alpha(0,05)$ maka $\mathrm{H} 0$ ditolak berarti ada hubungan kinerja perawat dalam memberikan asuhan keperawatan dengan kepuasan pasien rawat inap di ruang Multazam Rumah Sakit Islam Surabaya. Simpulan penelitian ini adalah kinerja perawat dalam memberikan asuhan keperawatan berpengaruh terhadap kepuasan pasien rawat inap. Perawat hendaknya tanggap terhadap keluhan dan harapan pasien.

Kata Kunci: Kinerja Perawat, Kepuasan, Pasien 


\section{PENDAHULUAN}

Kinerja merupakan suatu hasil kerja secara kualitas dan kuantitas yang dicapai oleh seorang perawat dalam melaksanakan tugasnya sesuai dengan tanggung jawab yang telah diberikan. Kinerja dapat dilihat atau diukur dengan menggunakan penilaian kinerja. Penilaian kinerja adalah sebagai alat yang dapat digunakan secara efektif untuk mengetahui kualitas dan kuantitas seorang perawat dalam memberikan pelayanan asuhan keperawatan. Perawat dapat menggunakan proses operasional kinerja untuk mengatur arah kerja dalam memilih, melatih, membimbing perencanaan, serta memberi penghargaan kepada perawat yang berkompeten, karena kinerja perawat yang kompeten dapat memenuhi tingkat kepuasan pasien.

Kepuasan pasien banyak dipengaruhi secara langsung oleh mutu pelayanan yang diberikan rumah sakit terutama yang berhubungan dengan fasilitas rumah sakit, proses pelayanan dan sumber daya yang bekerja di rumah sakit. Hasil wawancara dengan 10 orang pasien di Ruang Multazam pada bulan Desember 2014, diperoleh data bahwa 8 dari 10 orang pasien mengeluh tentang perawat yang kurang profesional dalam memberikan pelayanan kesehatan diantaranya mengatakan bahwa masih ada perawat yang tidak ramah dan acuh terhadap keluhan pasiennya, perawat juga tidak memperkenalkan diri kepada pasien maupun keluarga pasien, kurangnya penjelasan atau informasi dan komunikasi pada waktu memberikan asuhan keperawatan dan masih kurangnya monitoring dan observasi.

Data hasil kuesioner kepuasan pasien saat mahasiswa praktik manajemen bulan Desember 2014 di Ruang Multazam RSI Surabaya, didapatkan kepuasan pasien dari 10 pasien mengatakan $20 \%$ puas terhadap pelayanan perawat rawat inap di Ruang Multazam RSI Surabaya, sedangkan $80 \%$ mengatakan tidak puas terhadap pelayanan perawat rawat inap di Ruang Multazam RSI Surabaya.

Menurut Septiadi, 2008 dalam Rosmilawati, dkk, mengatakan bahwa data dari Organisasi Kesehatan Dunia (WHO) untuk Wilayah Asia Tenggara pada tahun 2010 menunjukkan bahwa sekitar 35\% pengguna jasa pelayanan kesehatan merasa puas terhadap pelayanan yang diberikan dan sekitar $55 \%$ menyatakan tidak puas. Penelitian Wirawan tentang tingkat kepuasan pasien rawat inap terhadap asuhan keperawatan disebuah rumah sakit di Jawa Timur, diperoleh informasi bahwa hanya $17 \%$ dari semua pasien rawat inap mengatakan puas terhadap pelayanan yang diterima sedangkan $85 \%$ mengatakan tidak puas (Susanti, 2005).

Penyebab terjadinya ketidakpuasan pasien dipengaruhi oleh banyak faktor antara lain yang berhubungan dengan kualitas produk dan jasa, harga, emosional, kinerja, estetika, karakteristik penduduk, pelayanan, lokasi, fasilitas, komunikasi, suasana, desain visual (Nursalam, 2014). Kepuasan pasien tidak lepas dari kinerja yang dilakukan oleh perawat dalam memberikan asuhan keperawatan. Kinerja perawat terdiri dari pengkajian, diagnosa keperawatan, rencana tindakan keperawatan, tindakan keperawatan, evaluasi, dan catatan keperawatan yang dipengaruhi oleh tiga faktor, yaitu: faktor individu, faktor psikologi, dan faktor organisasi. Faktor individu meliputi kemampuan dan keahlian, latar belakang, dan demografi seseorang. Faktor psikologi meliputi persepsi, attitude, personality, pembelajaran, dan motivasi, sedangkan faktor organisasi mencakup sumber daya, kepemimpinan, penghargaan, struktur, job disign. Perawat dalam memberikan asuhan keperawatan hal pertama yang dilakukan adalah pengkajian untuk memperoleh data sesuai dengan kondisi pasien, selanjutnya perawat dapat menegakkan diagnosa keperawatan yang sesuai dengan data yang diperoleh, dengan diagnosa keperawatan yang muncul akan dibuat rencana tindakan 
keperawatan yang akan dilakukan, kemudian untuk tindakan yang dilakukan perawat akan disesuaikan dari rencana tersebut dengan tepat, sehingga pasien akan memperoleh kesembuhan dengan cepat dan pasien akan merasa puas dengan kinerja perawat.

Dampak yang terjadi pada kinerja perawat bila pelanggan tidak puas, maka pelanggan tidak memanfaaatkan jasa pelayanan kesehatan dan menjadi pelanggan pihak pesaing, penjualan perusahaan akan menurun, laba rumah sakit akan menurun. Seorang pelanggan yang tidak puas akan menceritakan pengalamannya kepada 8 sampai 10 orang seperti kepada keluarga dan temannya (Tjiptono, 2006). Kualitas pelayanan dan kinerja perawat yang memuaskan, akan mendorong pasien untuk tetap memilih rumah sakit yang sama apabila membutuhkan pelayanan kesehatan.

Upaya yang bisa dilakukan untuk mengatasi pada masalah kurang ramahnya perawat pada saat melakukan tindakan keperawatan pada pasien dan sikap acuh perawat terhadap keluhan pasien, perawat tidak memperkenalkan diri kepada pasien maupun keluarga pasien, kurangnya penjelasan atau informasi dan komunikasi pada waktu memberikan asuhan keperawatan, dan masih kurangnya monitoring dan observasi adalah dengan cara memberikan pelayanan yang baik, pelayanan yang baik merupakan indikator terbentuknya kepuasan yang dirasakan oleh pasien sebagai pengguna jasa pelayanan. Serta meningkatkan kualitas dan etos kerja perawat, disiplin, cepat, tepat dan tanggap dalam memberikan pelayanan sehingga timbul kepuasan dari dalam diri pasien dan keluarga.

\section{METODOLOGI PENELITIAN}

Tujuan penelitian ini adalah untuk mengetahui hubungan kinerja perawat dalam memberikan asuhan keperawatan dengan kepuasan pasien rawat inap di
Ruang Multazam RSI Surabaya. Penelitian ini adalah penelitian survei analitik dengan pendekatan cross sectional. Populasi dalam penelitian ini adalah seluruh pasien yang dirawat di ruang Multazam Rumah Sakit Islam Surabaya. Teknik Sampling dalam penelitian ini adalah Probability Sampling dengan teknik Simple Random Sampling. Sampel pada penelitian ini adalah sebagian pasien yang dirawat di Ruang Multazam Rumah Sakit Islam Surabaya sebesar 39 responden. Waktu penelitian adalah pada bulan April 2015. Analisa data dengan SPSS 16 uji statistik Chi-Square dengan tingkat signifikan $\alpha=$ 0,05

\section{HASIL PENELITIAN}

a. Karakteristik responden berdasarkan kinerja perawat.

Tabel 1.1 Distribusi frekuensi responden berdasarkan kinerja perawat rawat inap di ruang Multazam Rumah Sakit Islam Surabaya bulan April 2015.

\begin{tabular}{cccc}
\hline No & $\begin{array}{c}\text { Kinerja } \\
\text { Perawat }\end{array}$ & Frekuensi & $\begin{array}{c}\text { Persentase } \\
(\%)\end{array}$ \\
\hline 1 & Baik & 19 & 48,7 \\
2 & Kurang & 20 & 51,3 \\
\hline & Jumlah & 39 & 100 \\
\hline
\end{tabular}

Sumber: Data Primer April 2015

Berdasarkan tabel 1.1 didapatkan dari 39 responden menyatakan sebagian besar $(51,3 \%)$ perawat mempunyai kinerja yang kurang.

b. Karakteristik responden berdasarkan kepuasan pasien.

Tabel 1.2 Distribusi frekuensi responden berdasarkan kepuasan pasien rawat inap di ruang Multazam Rumah Sakit Islam Surabaya bulan April 2015.

\begin{tabular}{cccc}
\hline No & $\begin{array}{c}\text { Kepuasan } \\
\text { Pasien }\end{array}$ & Frekuensi & $\begin{array}{c}\text { Persentase } \\
(\%)\end{array}$ \\
\hline 1 & Puas & 17 & 43,6 \\
2 & Tidak & 22 & 56,4 \\
& Puas & & \\
\hline & Jumlah & 39 & 100 \\
\hline
\end{tabular}


Sumber : Data Primer April 2015

Berdasarkan tabel 1.2 didapatkan dari 39 responden sebagian besar $(56,4 \%)$ mempunyai kepuasan pasien yang tidak puas.

c. Hubungan kinerja perawat dalam memberikan asuhan keperawatan dengan kepuasan pasien rawat inap di ruang Multazam Rumah Sakit Islam Surabaya.

\begin{tabular}{|c|c|c|c|c|c|c|}
\hline \multirow{3}{*}{$\begin{array}{l}\text { Kinerja } \\
\text { Perawat }\end{array}$} & \multicolumn{4}{|c|}{ Kepuasan Pasien } & \multirow{2}{*}{\multicolumn{2}{|c|}{ Total }} \\
\hline & \multicolumn{2}{|c|}{ Puas } & \multicolumn{2}{|c|}{ Tidak Puas } & & \\
\hline & $\mathrm{N}$ & $\%$ & $\mathrm{~N}$ & $\%$ & $\sum$ & $\%$ \\
\hline Baik & 12 & $\begin{array}{c}63, \\
2\end{array}$ & 7 & 36,8 & 19 & 100 \\
\hline Kurang & 5 & 25 & 15 & 75 & 20 & 100 \\
\hline \multirow[t]{2}{*}{ Total } & 17 & $\begin{array}{c}43, \\
6\end{array}$ & 22 & 56,4 & 39 & 100 \\
\hline & & & & & $\begin{array}{l}\rho= \\
0,03 \\
8\end{array}$ & $\begin{array}{c}\mathrm{OR}= \\
5,14 \\
3\end{array}$ \\
\hline
\end{tabular}

Tabel 1.3 Tabulasi silang kinerja perawat dalam memberikan asuhan keperawatan dengan kepuasan pasien rawat inap di ruang Multazam Rumah Sakit Islam Surabaya pada bulan April 2015.

Sumber : Data Primer April 2015

Berdasarkan tabel 1.3 dari 39 responden diperoleh hasil 19 responden menyatakan kinerja perawat baik, didapatkan sebagian besar $(63,2 \%)$ pasien merasa puas. Sedangkan 20 responden yang menyatakan kinerja perawat kurang didapatkan sebagian besar $(75 \%)$ pasien merasa tidak puas.

Berdasarkan uji Chi-Square didapatkan nilai $\rho(0,038)<\alpha(0,05)$ sehingga $\mathrm{H}_{0}$ ditolak yang artinya ada hubungan antara kinerja perawat dalam memberikan asuhan keperawatan dengan kepuasan pasien rawat inap di ruang multzam rumah sakit islam surabaya. Hasil Odds Ratio (OR) yaitu 5,143 (95\% CI: 1,299-20,360) maka dapat disimpulkan bahwa perawat yang mempunyai kinerja baik 5 kali lebih besar mendapatkan kepuasan pasien dibandingkan dengan perawat yang mempunyai kinerja kurang.

\section{PEMBAHASAN}

Kinerja perawat dalam memberikan asuhan keperawatan pada tabel 1.1 menunjukkan bahwa sebagian besar $(51,3 \%)$ perawat memiliki kinerja yang kurang. Artinya kinerja perawat masih dinilai kurang oleh sebagian besar pasien, dalam hal ini kinerja perawat dinilai berdasarkan persepsi pasien. Sesuai dengan pendapat Triyana (2013) bahwa Kinerja perawat adalah Perilaku kerja yang ditampilkan oleh perawat dalam memberikan asuhan keperawatan kepada pasien, yang digambarkan dalam pelaksanaan rencana tindakan yang ditentukan dengan maksud agar kebutuhan pasien terpenuhi secara maksimal berdasarkan implementasi kognitif, implementasi interpersonal, dan implementasi teknis.

Gambaran kinerja perawat dalam memberikan asuhan keperawatan ditinjau berdasarkan hasil kuesioner pada implementasi kognitif didapatkan hasil sebagian besar $(66,7 \%)$ pasien menyatakan perawat tidak memberikan informasi tentang kesehatan dengan baik dan sopan, sebagian besar $(61,5 \%)$ pasien menyatakan perawat tidak mempunyai cukup waktu untuk mendengarkan keluhan pasien dan memberikan kesempatan kepada pasien untuk bertanya, sedangkan sebagian besar $(56,4 \%)$ pasien menyatakan perawat tidak merapikan ruangan serta tempat tidur setiap hari serta menjaga ruangan tetap bersih. Melihat hal tersebut kinerja perawat pada pernyataan implementasi kognitif cenderung mengarah pada kinerja perawat dengan kategori kurang artinya pasien memandang kinerja perawat belum memenuhi kebutuhan pasien secara maksimal. Hal ini sesuai dengan pendapat Patrick M. Gallegos (2002) kriteria kinerja yang kurang adalah karyawan memenuhi sebagian besar harapan kerja minimum yang ditentukan bagi individu tersebut, mengambil beberapa tindakan mandiri, 
tetapi kadang tergantung pada pengawas pengarahan sehari-hari.

Kinerja perawat dalam memberikan asuhan keperawatan berdasarkan implementasi interpersonal didapatkan hasil sebagian besar $(53,8 \%)$ pasien menyatakan perawat tidak menanggapi keluhan pasien dengan sabar dan ramah dengan segera, sebagian besar $(56,4 \%)$ pasien menyatakan perawat tidak membaca doa sebelum menyuntik atau melakukan tindakan keperawatan sedangkan sebagian besar $(64,1 \%)$ pasien menyatakan perawat tidak memberikan penjelasan tentang tindakan yang akan dilakukan serta tidak memaksakan suatu tindakan kepada pasien apabila pasien tidak bersedia. Pada implementasi interpersonal dapat diartikan bahwa kinerja perawat masih dikatakan kurang. Hal ini bertentangan dengan pendapat Pohan (2007) bahwa kinerja yang baik Pada hakikatnya adalah kinerja yang dapat memenuhi kebutuhan yang dirasakan dengan sabar, sopan, tanggap dan perhatian terhadap keluhan pasien serta memberikan dorongan spiritual dalam melakukan tindakan keperawatan.

Kinerja perawat dalam memberikan asuhan keperawatan berdasarkan implementasi teknis didapatkan hasil hampir setengahnya $(43,6 \%)$ pasien menyatakan perawat tidak menyiapkan baskom dan air hangat untuk mandi setiap hari, sebagian besar $(53,8 \%)$ pasien menyatakan perawat tidak melakukan pengawasan pada pasien yang terpasang infus dan menanyakan keluhan terhadap penyakitnya, sebagian besar $(64,1 \%)$ pasien menyatakan perawat tidak mampu melakukan tindakan keperawatan sekali jadi, tidak diulang-ulang, sedangkan hampir setengahnya $(51,3 \%)$ pasien menyatakan perawat tidak melakukan konsultasi dengan dokter atau ahli medis lain jika ada hal-hal yang perlu diganti baik obat atau diet pasien. Artinya kinerja perawat dalam memberikan asuhan keperawatan pada implementasi teknis belum dirasakan baik oleh pasien. Hal ini bertentangan dengan pendapat Patrick $\mathrm{M}$. Gallegos (2002) yang menjelaskan bahwa kriteria kinerja yang baik adalah kinerja diatas normal, pencapaian serta hasil telah berada diatas harapan.

Kepuasan pasien pada tabel 1.2 menunjukkan bahwa dari 39 responden sebagian besar $(56,4 \%)$ menyatakan tidak puas terhadap kinerja perawat. Artinya lebih dari setengah pasien menyatakan tidak puas terhadap kinerja perawat. Hal ini sesuai dengan pendapat Nursalam (2014) yang mengatakan bahwa kepuasan pasien adalah suatu perasaan puas dan senang yang dirasakan pasien setelah membandingkan dengan pelayanan keperawatan yang diterima dengan harapannya, berdasarkan lima karakteristik: reliability, assurance, tangible, empathy, dan responsivenes.

Ditinjau berdasarkan 5 karakteristik kepuasan pasien terdapat 3 karakteristik yang dinilai tidak puas oleh responden yaitu assurance, tangible, dan empathy. Penelitian kepuasan pasien pada karakteristik assurance didapatkan sebagian besar $(53,8 \%)$ pasien menyatakan tidak puas terhadap kinerja perawat. Hal ini disebabkan karena kurangnya kemampuan perawat dalam memberikan asuhan keperawatan, yang dibuktikan dengan, perawat tidak memberi perhatian terhadap keluhan yang dirasakan, perawat tidak dapat menjawab pertanyaan tentang tindakan perawatan yang diberikan, perawat tidak jujur dalam memberikan informasi tentang keadaan pasien, perawat tidak selalu memberi salam dan senyum ketika bertemu, perawat tidak teliti dan terampil dalam melaksanakan tindakan keperawatan. Kepuasan pasien berdasarkan karakteristik tangible didapatkan hasil sebagian besar $(51,3 \%)$ menyatakan tidak puas. Adanya pasien yang menyatakan karakteristik tangible 
tidak puas dikarenakan perawat tidak memberikan kenyamanan kepada pasien, ini dibuktikan dengan pasien menyatakan perawat tidak memberi informasi tentang administrasi yang berlaku bagi pasien rawat inap di rumah sakit, perawat tidak selalu menjaga kebersihan dan kerapihan ruangan yang pasien tempati, perawat tidak menjaga kebersihan dan kesiapan alat-alat kesehatan yang digunakan, perawat tidak menjaga kebersihan dan kelengkapan fasilitas kamar mandi dan toilet, perawat tidak selalu menjaga kerapihan dan penampilannya. Kepuasan pasien berdasarkan karakteristik empathy didapatkan hasil sebagian besar $(51,3 \%)$ menyatakan tidak puas. Hal ini dikarenakan masih kurangnya perhatian perawat terhadap keadaan pasien yang dibuktikan dengan pasien menyatakan perawat tidak memberikan informasi kepada pasien tentang segala tindakan perawatan yang akan dilakukan, perawat tidak mudah ditemui dan dihubungi bila dibutuhkan, perawat tidak sering menengok dan memeriksa keadaan pasien seperti mengukur tensi suhu nadi pernapasan dan cairan infus, perawat dalam memberikan pelayanan memandang pangkat atau status tidak berdasarkan kondisi pasien, perawat tidak perhatian dan tidak memberikan dukungan moril terhadap keadaan pasien (menanyakan dan berbincang-bincang tentang keadaan pasien). Dengan adanya 3 karakteristik kepuasan pasien yang masih dalam kategori tidak puas tentunya akan berdampak terhadap pemanfaatan jasa pelayanan kesehatan. Hal ini sesuai dengan pendapat Tjiptono (2006) yang mengatakan bahwa seorang pelanggan yang tidak puas atas pelayanan yang diterima, mereka akan menceritakan pengalamannya kepada 8 sampai 10 orang seperti kepada keluarga dan temannya.

Hasil penelitian kepuasan pasien pada karakteristik reliability didapatkan hasil hampir setengahnya $(33,3 \%)$ menyatakan tidak puas. Melihat hal tersebut kepuasan pasien pada karakteristik reliability cenderung mengarah pada kategori puas dengan persentase $(66,7 \%)$. Hal ini dikarenakan perawat mampu menangani masalah perawatan dengan cepat dan profesional, perawat memberikan informasi tentang fasilitas yang tersedia cara penggunaannya dan tata tertib yang berlaku di rumah sakit, perawat memberitahu dengan jelas tentang hal-hal yang harus dipatuhi dalam perawatan, perawat memberitahu dengan jelas tentang hal-hal yang dilarang dalam perawatan, perawat mampu tepat waktu tiba di ruangan ketika dibutuhkan. Begitu juga dengan karakteristik responsiveness didapatkan hasil hampir setengahnya (41\%) pasien menyatakan tidak puas. Melihat hal tersebut kepuasan pasien pada karakteristik responsiveness cenderung mengarah pada kategori puas dengan persentase $(59 \%)$. Hal ini dikarenakan pasien menyatakan perawat bersedia menawarkan bantuan kepada pasien ketika mengalami kesulitan walau tanpa diminta, perawat segera menangani pasien ketika sampai diruangan rawat inap, perawat menyediakan waktu khusus untuk membantu pasien berjalan BAB BAK ganti posisi tidur dan lain lain, perawat membantu pasien untuk memperoleh obat, perawat membantu pasien untuk pelaksanaan pelayanan foto dan laboratorium di rumah sakit. Hal ini sesuai dengan pendapat Wijono (2004) apabila pelanggan merasa harapan dan kebutuhannya terpenuhi maka pelanggan puas, namun, bila tidak sesuai dengan kebutuhan dan harapannya maka yang dirasakan pelanggan adalah ketidakpuasan.

Hasil uji statistik dengan menggunakan uji chi square menggunakan SPSS for windows 16 diperoleh nilai $\rho=(0,038)<\alpha$ $(0,05)$ sehingga $\mathrm{H}_{0}$ ditolak yang artinya ada hubungan antara kinerja perawat dalam memberikan asuhan keperawatan dengan kepuasan pasien rawat inap di ruang Multazam Rumah Sakit Islam Surabaya, sesuai hasil tabulasi silang dari 
39 responden diperoleh hasil 19 responden menyatakan kinerja perawat baik, didapatkan sebagian besar $(63,2 \%)$ pasien merasa puas. Sedangkan 20 responden yang menyatakan kinerja perawat kurang didapatkan sebagian besar $(75 \%)$ pasien merasa tidak puas. Hal ini dapat diartikan bahwa apabila jasa yang diterima atau dirasakan sesuai dengan yang diharapkan, maka kinerja perawat akan dinilai baik atau memuaskan, sebaliknya apabila kualitas kinerja perawat lebih rendah dari yang diharapkan maka kualitas pelayanan dinilai buruk atau tidak memuaskan oleh pasien. Menurut Bustami (2011) ciri pelayanan yang bermutu adalah yang simpatik, disiplin, bertanggung jawab dan penuh perhatian sehingga memberikan kepuasan kepada pasien.

Kepuasan pelanggan adalah Tingkat kepuasan seseorang setelah membandingkan kinerja suatu barang atau jasa sekurang-kurangnya sama dengan apa yang diharapkan (Supranto, 2006). Dari hasil penelitian yang diperoleh peneliti bahwa kinerja perawat bukan diukur dari penyelenggara pelayanan tetapi dari pandangan atau persepsi pasien yaitu membandingkan pelayanan keperawatan yang diharapkan dengan pelayanan yang diterima. Cara yang tepat untuk melakukan perbaikan tentang tanggapan pasien tersebut adalah pro aktif terhadap keluhan dan harapan pasien dengan cara melakukan survei kepuasan pasien, sistem keluhan dan saran. Terciptanya pelayanan yang baik tentu akan menciptakan kepuasan terhadap pasien.

Kepuasan pasien dipengaruhi oleh banyak faktor antara lain kualitas produk dan jasa, harga, emosional, kinerja, estetika, karakteristik produk, pelayanan, lokasi, fasilitas, komunikasi, suasana, dan desain visual (Nursalam, 2014). Kepuasan pasien tidak lepas dari kinerja yang dilakukan oleh perawat dalam memberikan asuhan keperawatan. Kinerja perawat yang baik merupakan suatu pelayanan yang dapat memenuhi kebutuhan pasien dan merupakan indikator terbentuknya kepuasan yang dirasakan oleh pasien, sehingga pada akhirnya dapat memberikan beberapa manfaat diantaranya terjadinya hubungan yang harmonis antara petugas kesehatan dan responden yaitu dengan memberikan dasar yang baik bagi terciptanya loyalitas responden. Hubungan yang baik akan menimbulkan kepercayaan atau kredibilitas dengan saling menghargai, menjaga rahasia, saling menghormati, responsif, dan memberi perhatian.

\section{KESIMPULAN DAN SARAN}

Berdasarkan hasil penelitian, dapat disimpulkan bahwa sebagai berikut:

Kinerja perawat dalam memberikan asuhan keperawatan sebagian besar menyatakan kurang di ruang rawat inap Multazam Rumah Sakit Islam Surabaya. Kepuasan pasien rawat inap sebagian besar menyatakan tidak puas terhadap kinerja perawat di ruang Multazam Rumah Sakit Islam Surabaya Ada hubungan antara kinerja perawat dalam memberikan asuhan keperawatan dengan kepuasan pasien rawat inap di ruang Multazam Rumah Sakit Islam Surabaya.

Dari simpulan diatas, maka saran dari peneliti adalah:

Dalam rangka menjaga dan menyempurnakan kinerja perawat, perawat perlu meningkatkan jenjang pendidikannya serta memperbanyak mengikuti pelatihanpelatihan tentang keperawatan. Rumah sakit harus meningkatkan jenjang pendidikan perawatnya karena di ruang Multazam rata-rata jenjang pendidikan perawatnya masih D3 dan SPK, serta meningkatkan SDM nya dengan memberikan pelatihan-pelatihan terkait tindakan keperawatan, ini penting agar dapat memenuhi tuntutan terhadap pelayanan keperawatan yang diberikan sesuai dengan kebutuhan pasien guna 
memenuhi harapan dan kepuasan pasien untuk mendapatkan suatau layanan yang baik. Diharapkan agar peneliti selanjutnya dapat melanjutkan penelitian faktor-faktor lain yang dapat mempengaruhi kinerja perawat dalam memberikan asuhan keperawatan dengan kepuasan pasien.

Daftar Pustaka:

1. Bustami. 2011. Penjaminan Mutu Pelayanan Kesehatan Dan Askeptabilitasnya. Jakarta : Erlangga.

2. Depkes RI. 2005. Pedoman Kinerja Perawat Dan Bidan Di Rumah Sakit. Jakarta : Depkes RI.

3. Hidayat, A.Aziz. 2009. Metode Penelitian Kebidanan Teknik Analisis Data. Jakarta : Salemba Medika.

4. Ilyas, Yaslis. 2004. Perencanaan Sumber Daya Manusia Rumah Sakit, Teori, Metoda, Dan Formula. Jakarta : fakultas ilmu kesehatan masyarakat universitas indonesia.

5. Kartono, Kartini. 2008. Psikologi Wanita Mengenai Gadis Remaja Dan Wanita Dewasa. Bandung : Mandar Maju.

6. Kotler, Philip. 2005. Manajemen Pemasaran Edisi Kesebelas Jilid I. Jakarta : PT Intan Sejati Klaten.

7. Mangkunegara. 2006. Evaluasi Kinerja SDM. Bandung : Refika Aditama.

8. Muninjaya., A.A. Gde. 2011. Manajemen Mutu Pelayanan Kesehatan. Jakarta : EGC

9. Nasrudin, E. 2010. Psikologi Manajemen. Bandung : Pustaka Setia.

10. Nasution, M.N. 2005. Manajemen Mutu Terpadu (Total Quality
Manajemen) Edisi 2. Jakarta : Ghalia Indonesia.

11. Notoatmodjo, S. 2010. Metodelogi Penelitian Kesehatan. Jakarta : PT.Rineka Cipta.

12. Nursalam. 2013. Metodelogi Penelitian Ilmu Keperawatan Pendekatan Praktis Edisi 3. Jakarta : Salemba Medika.

13. Nursalam. 2014. Manajemen Keperawatan Aplikasi Dalm Praktik Keperawatan Profesional Edisi 4. Jakarta : Salemba Medika.

14. Pohan, Imbalo S. 2007. Jaminan Mutu Layanan Kesehatan; Dasar-Dasar, Pengertian, Dan Penerapan. Jakarta : EGC.

15. Robin dan Judge. 2008. Perilaku Organisasi (Organizational Behavior) Edisi 12. Jakarta : Salemba.

16. Siregar, M. 2008. Pengaruh Motivasi Terhadap Kinerja Perawat Pelaksana Di Ruang Rawat Inap. Http://repository.usu.ac.id. Diakses tanggal 05 februari 2015, 20.00 WIB.

17. Supranto, Johames. 2006. Pengukuran Tingkat Kepuasan Pelanggan: Untuk Menaikkan Pasar. Jakarta : Rineka Cipta.

18. Tjiptono, F. 2006. Manajemen Jasa, Edisi Ke Empat. Jakarta : Andi.

19. Triyana, Yani F. 2013. Teknik Prosedural Keperawatan. Jogjakarta : D-MEDIKA.

20. Wijono, Djoko. 2000. Manajemen Mutu Pelayanan Kesehatan: Teori, Strategi, Dan Aplikasi. Surabaya : Airlangga University Press. 